Krzysztof Karolczak

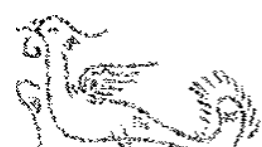

\section{ELITY RZĄDZĄCE W JAPONII}

\section{Robert L. Cutts, An Empire of Schools. Japan's Univer-} sities and the Molding of a National Power Elite, wstęp Chalmers Johnson, An East Gate Book, M. E. Sharp, Armonk New York 1997, s. 268.

Na wstepie anegdota: pewnego letniego dnia, bęac zaproszonym na kolację do jednej z wielu restauracji w tokijskiej dzielnicy Shibuya, wyjątkowo nie mając przy sobie planu miasta i nie mogąc trafić na miejsce spotkania, postanowiłem zapytać o drogę. Ponieważ jednak pora była wieczorna, a dzielnica ta to słynne centrum rozrywki, w jakim dominują osoby przybyłe tam $z$ innych rejonów miasta, trudno mi było zdecydować się na wybór z tłumu kogoś, kto wyglądałby na dobrze zorientowanego w labiryncie jej uliczek i mógł wskazać drogę do „mojej" restauracji. W odruchu rozpaczy (do spotkania pozostało tylko pięć minut, a ja w dalszym ciagu tkwiłem przy wyjściu ze stacji metra), zaczepiłem dwie młode dziewczyny, które na widok gaijina, to jest ,cudzoziemca $\mathrm{z}$ Zachodu", do tego mówiącego „po amerykańsku", chciały po prostu uciec. Majac jednak w pamięci wcześniejsze doświadczenia, równolegle do pytania, podałem im swoją wizytówkę. I tu, jak za dotknięciem czarodziejskiej różdżki —po zorientowaniu się, że jestem sensei (w tym przypadku „profesorem") i to do tego Uniwersytetu Tokijskiego, a nie zwykłym podrywaczem, jakich można najczęściej spotkać na Shibuya — stosunek tych dziewczyn do mnie zmienił się diametralnie: były pełne szacunku i chętne do pomocy, choć ich znajomość języka „amerykańskiego" pozostawiała wiele do życzenia. Tak oto zadziałała na nie magia jedne go tylko słowa: Todai.

Todai (czyli Tokyo Daigaku — Uniwersytet Tokijski) — to więcej niż uniwersytet, i to nie tylko dlatego, że we wszystkich rankingach przewodzi ponad 500 wyższym uczelniom $\mathrm{z}$ całej Japonii (w tym ponad 100 w samym Tokio). To miejsce magiczne dla polityki japońskiej, bo stąd wywodzi się większość elity politycznej - i to nie tylko tej rządzącej, ale i tej „od zawsze" pozostającej w opozycji: w połowie lat osiemdziesiątych nawet liderzy Japońskiej Partii Komunistycznej posiadali dyplomy tej uczelni. Przede wszystkim był jednak Uniwersytet kuźnia kadr politycznych i gospodarczych rządzących Japonią przez ostatnie kilkadziesiąt lat, był „bastionem japońskiego kapitalizmu i świata biznesu" i. Jaki bowiem inny wniosek można by wysnuć $\mathrm{z}$ faktu, iż w połowie lat osiemdziesiątych $21 \%$ członków japońskiego parlamentu było absolwentami właśnie Todai; ten sam dyplom posiadali wszyscy trzej przewodniczący najbardziej znaczacych stowarzyszeń gospodarczych: Federacji Organizacji Gospodarczych, Federacji Stowarzyszeń Pracodawców oraz Japońskiej Izby Handlu i Przemysłu, jak i legitymowało się nim 15\% wszystkich menadżerów 1.865 spółek rejestrowanych przez tokijska giełde ${ }^{2}$ ? A ponadto każdego roku wśród nowo zatrudnionych w Ministerstwie Finansów oraz wszelkiego typu innych instytucjach finansowych (giełdzie, bankach, Państwowej Agencji Podatkowej) ponad 75\% stanowią absolwenci tego Uniwersytetu; podobnie ma się rzecz w przypadku Ministerstwa Handlu Zagranicznego i Przemysłu (też 75\%), Ministerstwa Spraw Wewnętrznych czy Narodowej Agencji Policji (72\%). Zaś w połączeniu z czterema innymi uniwersytetami (Uniwersytetu Kyoto, tokijskim Hitotsubashi oraz dwoma prywatnymi, mającymi siedzibę też w Tokio: Kejo i Waseda), tworzy tzw. „wielką piątkę" japońskich wyższych uczelni?

Ponieważ „Japończycy lubia rozróżniać pomiędzy tymi, którzy aktualnie dzierżą władzę a tymi, którzy moga uzyskać możliwość wejścia na taką drogę. Japońskie określenia na te różnice są na pozór wieczne i bardzo stare. Zaliczyć do nich można tatemae (pozory) i honne (rzeczywistość), seto (zewnetrzny) i uchi (domowy), omote (oficjalny) i ura (ukryty), kagemusha (marionetka) i kuromaku (poza sceną), oraz ningyo (lalka) i kuroka (lalkarz)..."3, to aby zrozumieć tzw. „demokrację japońską", należy zanalizować wszystkie składajace się na nia czynniki, a zatem niezbedne jest również zbadanie wpływów (często właśnie nieformalnych) uniwersytetów na kształtowanie japońskich elit. Książka Roberta L. Cutts'a jest właśnie próba takiej analizy, a jednocześnie ,,pokazuje, jak proces edukacji [...] produkuje mniej lub bardziej jednakowych, narodowo nastawionych przywódców dla całego systemu"4.

Robert L. Cutts ,An Empire of Schools. Japan's Universities and the Molding of a National Power Elite", An East Gate Book, M. E. Sharpe, Armonk, New York 1997, s. 4. 2 Ibidem, s. 4.

Chalmers Johnson „Japan: Who Governs? The Rise of the Developmental State",

W. W. Norton \& Company, New York - London 1995, s. 218.

Chalmers Johnson, przedmowa do książki Cutts'a, op. cit., s. XI 
Fakty przywoływane przez autora pozwalają według niego na sformułowanie „siedmiu prawd", odnoszących się do wpływu absolwentów pięciu najważniejszych uniwersytetów na proces rządzenia traponi4 ${ }^{5}$ :

Po pierwsze, tych pięć uniwersytetów jest źródłem ,esprit de corps, lojalności, przestrzegania zwyczajów i odpowiedzialności", niezbędnych do odniesienia sukcesu $\mathrm{w}$ walce o władzę toczonej przez biurokrację z politykami;

Po drugie, rzeczywiste procesy podejmowania decyzji i zarządzenia, niezależnie od tego, kto jest „graczem", mają charakter głęboko nieformalny i dlatego zależą głównie od cech osobowości oraz wzajemnych stosunków między liderami, a te ostatnie znaczą o wiele więcej niż oficjalnie zajmowane stanowiska oraz formalne struktury władzy;

Po trzecie, konflikty pomiędzy instytucjami, tak publicznymi, jak i prywatnymi, są tak ostre i cechowane przez nieufność, a nawet wrogość, jak między ugrupowaniami politycznymi, co powoduje, że politycy polegają bardziej na elitach administracyjnych podczas formułowania i realizacji polityki rządowej;

Po czwarte, prawdziwe cele rządzących są często prawie zupełnie ukryte przed społeczeństwem, które traktowane jest przez nich w istocie lekceważąco;

Po piąte, możliwość manipulowania informacją, jest kluczem do sukcesu w walce elit, na każdym jej poziomie i w każdej skali;

Po szóste, przynależność do grona absolwentów tych uniwersytetów w istocie umożliwia ucieczkę od odpowiedzialności nawet tych ,pseudofachowców", którzy mogą i powodują katastrofy szkodzące całemu państwu (na przykład efekty „,bubble economy");

Po siódme, istnienie wpływowych ugrupowań ich absolwentów stwarza zagrożenie uformowania się władzy sięgającej znacznie dalej niż wielu Japończyków i obcokrajowców może sobie to wyobrazić.

$\mathrm{Na}$ potwierdzenie swych tez Cutts opisuje japoński ,żelazny trójkąt władzy", czyli wzajemne relacje pomiędzy biurokracją państwową, wielkim biznesem i politykami, jakie podczas długoletnich rządów Partii LiberalnoDemokratycznej podlegały patologicznemu zwyrodnieniu, za co przynajmniej częściową winą autor obarcza ukształtowanie się ,imperium Todai". Ilustracją owych niezdrowych proporcji mogących stanowić zagrożenie dla niezależnego i demokratycznego podejmowania decyzji, także w sferze gospodarczej, jest fakt, iż prawie dwie trzecie dyrektorów zarządzających różnymi firmami należącymi do keiretsu Mitsubishi, w połowie lat dziewięćdziesiątych stanowili absolwenci ,wielkiej piątki". Przy czym w niektórych firmach ich dominacja jest jeszcze większa niż we wspomnianych powyżej ministerstwach (na przykład, w Banku Mitsubishi jest ich 42 na ogólną liczbę 45, a w browarze Kirin - 31 na 35$)^{5}$.

Praca Cutts'a jest jednocześnie pewnego rodzaju oceną całego japońskiego systemu edukacji. Czy jest ona obiektywna? Chyba tylko po części. Nie jest, gdyż chyba jednak oceny formułuje tu sie z pozycji amerykańskich i na podstawie norm przyjętych w tamtym społeczeństwie. Jest jednak zasadna, bo z kolei wskazuje na wiele zjawisk, które dla przeciętnego Japończyka są tak oczywiste, iż nie budza jego krytycznej refleksji. Warto więc poświęcić nieco czasu na przeczytanie owych 12 rozdziałów traktujących o ,szkolnym imperium", by nie tyle lepiej zrozumieć system japońskiego szkolnictwa (o którym $\mathrm{w}$ książce $\mathrm{w}$ sumie pisze się niewiele), ale raczej mechanizmy rządzące społeczeństwem japońskim.

Choć w swym wstępie Johnson (za Cutts'em) twierdzi, iż Todai „nie odgrywa tej samej roli w tworzeniu japońskiego establishmentu, co, na przykład Oxford i Cambridge w Wielkiej Brytanii", fakty zdają się przeczyć tej opinii. Na pewno zaś w świadomości społecznej Uniwersytet Tokijski jest utożsamiany z czymś nadzwyczaj ważnym i cennym. Swiadczyła o tym najlepiej właśnie głębokość ukłonu przede mną składanego przez nowo poznawanych Japończyków, z chwilą, gdy dowiadywali się, że jestem „profesorem" tej uczelni.

Krzysztof Karolczak

\footnotetext{
${ }^{5}$ Por. Cutts, ss. 177-178.
} 